\title{
DOKUMENTACJA NOWSZYCH KSIĘGOZBIORÓW. Z ZAGADNIEŃ TEORII I PRAKTYKI
}

Księgozbiory - chyba nie trzeba tego na tym miejscu uzasadniać - nie są po prostu zbiorem ksiąg, ale odrębnym bytem, stanowiącym nową jakość. Uszczknięcie z nich paru pozycji nie zmienia ich istoty ale osłabia konstrukcję, tak jak wyrwanie cegły nie koniecznie musi zagrażać całości budynku. Sa jednak w murze kamienie, bądź położone w fundamentach, bądź w ścianie już osłabionej licznymi ubytkami, których usunięcie powoduje rozsypanie się struktury - zamiast stabilnego układu mamy do czynienia ze stosem odrębnych kamieni, cegieł lub książek.

Badanie księgozbiorów jest nie tylko składaniem opisów dzieł w nim znajdujących się, ale też refleksją nad okolicznościami, które je połączyły. Koncepcja zbioru odzwierciedla osobowość osoby lub osób, które go stworzyły. Biblioteki historyczne, w których gromadzenie zamknięto, stanowią ważne źródło nie tylko dla poznania sylwetek twórców i właścicieli, ale również ducha czasu, w którym żyli. Mylą się jednak ci, którzy w zachowanym zespole ksiąg literata, naukowca, czy polityka chcą po prostu widzieć spis jego lektur.

Nieco inny status przysługuje nawet najstarszym księgozbiorom, które się rozwijają i są nadal nastawione na współczesnego czytelnika. W nich nowe książki tworzą konglomerat z dawnymi, w których rozróżnienie kolejnych warstw nie jest tatwe.

Jeśli mamy do czynienia $z$ choćby częściowo zachowanym księgozbiorem powstałym przed wiekami lub przynajmniej w I poł. XIX wieku nie powinno być wątpliwości, że każdy zespół książek, który przetrwał w naszym kraju wszelkie zawirowania dziejowe godzien jest ochrony i udokumentowania jako zabytek. Niekiedy udaje się zachować jedynie opis rozproszonego lub zniszczonego zbioru. To również stanowi cenne źródło nie tylko dla wąsko pojętego księgoznawstwa, ale dla historii kultury narodowej.

Od połowy XIX wieku mamy kolejny przełom w rozwoju technik drukarskich, a zwłaszcza popiernictwie, który spowodował znaczny wzrost księgozbiorów domowych. Z czasem zatraca się poczucie celowości ich przechowywania i opisywania jako wartościowego składnika majątku godnego wspomnienia, np. w testamencie'. Nawet biblioteki luminarzy naszej kultury były rozpraszane często bez śladu. Niekiedy udawało się dokonać ich opisu ex post - tak stało się np. z księgozbiorem Bolesława Prusa, opracowanym przez Halinę llmurzyńską i Agnieszkę Stępnowską (1965).

Kiedy w początku naszego wieku Wiktor Wittyg podjał publikacje „Ekslibrisów bibliotek polskich" (1903-1907) nie przyświecała mu myśl o artystycznych walorach 
księgoznaku, chciał po prostu przypomnieć setki zaginionych księgozbiorów, dać świadectwo kulturalnej aktywności narodu, któremu odmawiano praw. Podobny cel przyświecał Edwardowi Chwalewikowi, który rejestrował zbiory polskie (1 wydanie z 1916 r.). Dzialanie bibliofilów, a następnie praca ośrodków księgoznawczych przyczynity się do uświadomienia historycznego znaczenia księgozbiorów. Odzywają się głosy o konieczności zachowania każdej spuścizny po prominentnej osobie. Kolekcjonerzy marzą, aby dorobek ich życia pozostał nietknięty i niekiedy już za życia poszukują instytucji, która przyjęłaby ich zbiory pod swój dach i zapewnila ich ochronę.

Znacznie ostrożniejsi w tej sprawie są bibliotekarze-praktycy, którzy wiedzą, co to znaczy przejąć księgozbiór, jeśli trzeba go zachować w całości i jakie idą za tym problemy i koszta zwiazane z opracowaniem i przechowywaniem książek, zwykle w znacznej części dublujących zbiory już posiadane.

Jeśli dublowanie nie występuje, znaczy to najczęściej, że uzyskana kolekcja wykracza poza dotychczasowy zakres gromadzenia i być może nie szybko znajdzie w nowym miejscu zainteresowanych czytelników.

Jak pogodzić te pozornie sprzeczne interesy, to problem do rozwiązania. Wiele milionów ksiażek znajduje się w posiadaniu wybitnych kolekcjonerów, naukowców, artystów, polityków. Co roku prasa donosi o śmierci wielu osobistości uznawanych za wybitne - co począć, gdyby przekonanie o konieczności zachowania ich zbiorów rozszerzyło się?

Obecna próba rozważenia tego zagadnienia, jako punkt wyjścia próbuje przyjąć dwa różne doświadczenia - wieloletniego bibliotekarza-praktyka, który niejednokrotnie stykał się z problemem przejmowania spuścizn i wiążącymi się z tym trudnościami, a równocześnie osoby czułej na potrzeby nauki księgoznawczej i argumenty bibliofilów.

Kiedy mamy do czynienia z nowszym księgozbiorem, z końca XIX wieku lub całkiem współczesnym, należy pieczołowicie rozważyć jego status, a następnie możliwe sposoby jego wykorzystania w systemie bibliotecznym i muzealnym.

Z pełną świadomością niedoskonałości wszelkich klasyfikacji spróbujmy dokonać spisu typowych sytuacji księgozbiorów, które przestały spełniać swoją rolę i muszą zmienić właściciela lub pójść w rozsypkę.

1. Biblioteki-instytucje, samodzielne księgozbiory kiedyś dostępne dla publiczości, po ich organizacyjnej likwidacji zwykle rozpraszane lub wcielane do innych księgozbiorów, najczęściej bez wyodrębnienia. Szkoda, że jak się wydaje, nie udało się zachować w całości, wraz ze sprzętem i katalogami żadnejXIX, czy XX-wiecznej czyteini ludowej, ani prywatnej wypożyczalni zarobkowej.

2. Księgozbiory rodzinne - biblioteki domowe gromadzone przez kolejne pokolenia, które posiadały często obok książek również czasopisma, rękopisy, druki ulotne itp. Zniszczenie dworów, wysiedlania, przesiedlania ludności, trudności mieszkaniowe i finansowe polskiej inteligencji powodują powolną zatratę tej formy kolekcji, choć ciągle istnieją w polskich domach cechy zbiorów charakterystyczne dla tej formacji. Obok ciągłości występuje w nich zmienność, obrazująca zainteresowania i potrzeby kolejnych spadkobierców. Rzadko mamy do czynienia z pełną konsekwencji kontynuacją, raczej z elementami rodzinnymi, kilka pamiątkowych 
pozycji zachowanych po przodkach we współczesnej bibliotece. Dawniejsze części takich księgozbiorów są zwykle martwe i przechowywane ze względów sentymentalnych, lub na zasadzie inercji.

3. Księgozbiory jednopokoleniowe, które z powodu śmierci, wyjazdu właściciela lub innych okoliczności muszą znaleźć nowe miejsce. Są wśród nich:

a) kolekcje bardzo wyspecjalizowane, gromadzone świadomie z nastawieniem naukowym lub bibliofilskim, najczęściej połączone $z$ bardziej ogólnym, użytkowym zbiorem, taką była kolekcja Jana Michalskiego znajdująca się dziś w IBLu.

b) zbiory specjalistów, którzy konsekwentnie interesowali się jakimś tematem i nabywali książki z określonej dziedziny. Byli to często ludzie zasłużeni dla nauki lub kultury, posiadający szerokie kontakty krajowe i zagraniczne. $W$ ten sposób powstawaly wartościowe kolekcje bez specjalnych zabiegów bibliofilskich - po prostu kumulowały się bieżące zakupy i dary od kolegów-specjalistów. Takie zbiory szczególnie rozrastały się u osób, które przez całe życie nie były skłonne ani wyrucić, ani sprzedać żadnego druku. Taki charakter mają przechowywane w KULu biblioteki po profesorze Wacławie Borowym i Ignacym Chrzanowskim oraz w Bibliotece Uniwersytetu Łódzkiego spuścizna po Pawle Hulce-Laskowskim.

c) cenne pozycje można znaleźć w zbiorach bardzo przypadkowych, narastających spontanicznie $w$ związku ze zmieniającymi się zainteresowaniami właścicieli, prezentami, spadkami, wypożyczeniami „na zawsze”. Takie zbiory są zwykle niedoceniane przez właścicieli i praktycznie niedostępne.

Wszystkie wspomniane rodzaje kolekcji bywają oferowane jako dary lub do zakupu bibliotekom. Szczególną pozycję zajmują tu zbiory, a nawet ich części, wiążące się $z$ osobami, które odegrały określoną rolę $w$ kulturze lub nauce. Szczególnie cenne są zestawy dzieł stanowiące źródła wyjaśniające warsztaty twórców. Ze znanych zbiorów można tu wymienić bibliotekę Juliana Tuwima w Muzeum im. Mickiewicza w Warszawie, czy całkiem odmienny w pomyśle zbiór ludowego pomorskiego wydawcy i pisarza Walentego Fiałka w Ksiażnicy Miejskiej w Toruniu.

Pozostaje jednak nie rozwiązane pytanie, które zbiory są współcześnie godne zachowania w całości, a które słuszniej będzie skazać na parcelację.

Dziś już historycznym modelem jest budowanie na bazie istniejącego, dawnego zbioru nowej biblioteki. Niezależnie od tego, czy pozostaje on magazynowo wyodrębniony, czy też scalony $z$ resztą księgozbioru. $W$ takim przypadku przy dalszym gromadzeniu unika się dublowania zdobytych w ten sposób pozycji oraz bierze pod uwagę ich specyfikę przy kształtowaniu księgozbioru w przyszłości. Czas zakładania nowych bibliotek, który trwał zarówno po zdobyciu niepodległości, jak i po II wojnie światowej, dobiegł w Polsce końca. Dziś trzeba troszczyć się o utrzymanie i rozwój istniejących placówek. Wydaje się nie tylko mało prawdopodobne, aby mógł istnieć w kraju prywatny zbiór tak wartościowy, jak wspomniana kolekcja Jana Michalskiego, ale równocześnie trudno wyobrazić sobie polską instytucję, na którą tego typu dar, opatrzony zastrzeżeniami zachowania jego integralnej całości nie sprowadziłby poważnych klopotów. Tymczasem zdarza się, że zarówno właściciele, jak i ich spadkobiercy oraz mniej lub bardziej samozwańczy działacze kontynuują naciski, aby tworzyć kolejne biblioteki-pomniki. Zniechęceni 
postawą dużych bibliotek i muzeów niektórzy myślą o obdarowaniu placówek regionalnych kłopotliwymi spuściznami. W nich, mimo lokalnych ambicji, brak zwykle kadry bibliotekarskiej, warsztatu pomocniczego, miejsca, zainteresowanych czytelników, wreszcie pieniędzy. Co roku odchodzą twórcy, o których zasługach mówi się wiele, czas weryfikuje miejsce w kulturze, a trzeba parę dziesięcioleci, aby stwierdzić, kto się w niej ostał. Tymczasem kolekcja złożona w bibliotece, czy muzeum zaczyna żyć nowym życiem i trudno jest przyznać się do pomylki i sprawę zlikwidować. Nie wymienimy tu przykładów - „nomina sunt odiosa”. Wydaje się jednak, że epoka twórców-instytucji pozostawiających wyposażone siedziby i zbiory, których zachowanie było i jest sprawą oczywistą, jak to się stało w wypadku Kasprowicza, czy Iwaszkiewicza przeminęla i nie tylko ze względu na być może chwilowe nasze ubóstwo nie warto myśleć o mnożeniu tego rodzaju inicjatyw.

Proponowany model dokumentacji biblioteki, której rola w rękach poprzedniego właściciela się skończyła, może dziś wyglądać następująco: książnica lub muzeum, przejmując spuściznę włącza do zbiorów:

A) zespoły rękopisów, B) specjalne kolekcje książek, jeśli były one pomyślane bibliofilsko i konsekwentnie zbudowane, nie dublujące w całości istniejących zbiorów, C) egzemplarze dedykowane, z adnotacjami, marginaliami, robocze $i$ inne bezpośrednio związane z osobą lub instytucją, do której należały, D) inne książki, rzeczywiście uzupełniające zbiory biblioteki przejmującej spuściznę.

Wszelkie inne części zbiorów powinny podlegać selekcji. W miarę możności należy zachować informację o ilości i rodzaju wyselekcjonowanych pozycji. W negocjacjach z przekazującymi spuściznę należy zastrzec prawo do dysponowania powstałymi dubletami i drukami zbędnymi lub zwrócić je spadkobiercom. Jeśli nie ma na to zgody, a obiekty opisane w punktach od a do $d$ nie przeważają w zbiorze i nie reprezentują wysokiej klasy, warto zdecydować się na odrzucenie daru. Natomiast w wypadku, gdy istnieje szansa na uzyskanie cennych zespołów, nie należy skapić na ich zakup. Twierdzimy, że najlepszą formą przekazania zbiorów rodzinnych bibliotece jest ich sprzedaż, choćby za symboliczna sumę. Ta forma upewnia, że biblioteka jest rzeczywiście zainteresowana nabytkiem, nie zaś skuszona darmochą, a równocześnie uchyla wszelkie roszczenia dawnych właścicieli, ich spadkobierców itp. W praktyce światowej biblioteki z zasady skrupulatnie wypełniają swoje zobowiązania i zastrzeżenia ofiarodawców. Wiemy, że polskie instytucje mają niekiedy mniej rygorystyczny stosunek do swych zobowiazań i pienwotne umowy bywają lamane i tak np. w Łodzi zbiory Bartoszewiczów wbrew życzeniom fundatorów podzielono między Bibliotekę, Muzeum i Archiwum.

Fakt selekcji otrzymanych zbiorów instytucja przejmująca może rekompensować ich właścicielom i darczyńcom przez lepsze wyeksponowanie i podkreślanie wartości, przez organizowanie wystaw, których katalogi opisywałyby cenniejsze obiekty. W niektórych bibliotekach istnieją stałe ekspozycje prezentujące cenniejsze kolekcje, np. w Królewskiej Bibliotece w Brukseli zorganizowano witryny upamiętniające wybitnych twórców, gdzie obok części księgozbiorów pokazywano różne pamiątki, a nawet meble. W drukowanych informatorach i tablicach wewnątrz biblioteki można eksponować nazwiska wybitnych osób, których fragmenty księgozbiorów znajdują się $w$ gmachu ${ }^{2}$. Jednym z dobrych sposobów upamiętniania 
księgozbioru jest wykonanie odpowiedniego okolicznościowego ekslibrisu. Wreszcie, nawet $w$ wypadku, gdy biblioteka praktycznie idzie w rozsypkę warto pokusić się o jej opisanie, może to być np. wdzięczny temat bibliotekoznawczych prac magisterskich. Jedną z form takiego opisı może być oferta antykwarska. Warto propagować ideę, aby w razie sprzedaży całości lub części poważnego zbioru wykonywano osobny druk, który pozostałby jako trwały ślad współżycia czlowieka z ksiażkami. Katalogi aukcji i wyprzedaży bibliotek stanowią na świecie cenne źródło do poznania rozproszonych kolekcji i przedmiot zainteresowania księgoznawców. Niestety, w Polsce pokutuje pogląd, że sprzedaż książek jest czynnością wstydliwą i większość takich transakcji unika rejestracji. Jednak i u nas istnieją katalogi aukcji, w których wskazano właściciela godzącego się na licytację zbioru. Tak sprzedano m.in. spuścizny po Antonim Trepińskim, Antonim Broszu, Juliuszu W. Gomulickim.

Specyficzną formą dokumentacji zbioru i jego właściciela jest rejestracja znajdujących się w nim dedykacji, co, pomijając walory literackie niektórych wpisów, umożliwia odtworzenie powiązań i przyjaźni twórczych. Mamy już kilka publikacji zawierających zbiory dedykacji, do najciekawszych z nich należy „Ex-Libris Juliana Tuwima", opublikowany przez Muzeum Adama Mickiewicza w roku 1964.

Popularnym sposobem ujawnienia zawartości księgozbioru są chwilowe kolekcje organizowane jako wystawy, zwłaszcza jeśli opracowano katalogi ze wskazaniem właścicieli całości lub części eksponowanych zbiorów.

Przy opisie biblioteki lub wystawy bibliofila, z jej nieuniknioną niekompletnością, powstaje jednak szansa zbudowania informatora, zawierającego dane bibliograficzne, które trudno uzyskać inną droga, zwłaszcza, jeśii stosowane są kryteria doboru oparte na subiektywnej ocenie takiej, jak np. książki najpiękniejsze, rara, curiosa, erotica. Niełatwo stworzyć pisane normy, co jest estetyczne, a co nie, co jest tylko romantyczne, a co już erotyczne, wreszcie, co znaczy popularne lub mlodzieżowe. W roku 1986 w Muzeum Literatury im. Adama Mickiewicza eksponowano ksiażki z kilku prywatnych i państwowych kolekcji pn. „Sztuka polskiej książki literackiej 1918-1939". Dobór dokonany przez komisarza wystawy Jana Strausa pozwolił na stworzenie przydatnej listy najważniejszych artystów ksiażki polskiej międzywojennego dwudziestolecia oraz najbardziej typowych ich prac.

Innym przykładem sa katalogi kolekcji lub ekspozycji, których przedmiot jest trudny do zbibliografowania ze względu na rozproszenie materiałów, jak np. małonakładowa książka artystyczna, dawna książka dziecięca, druki ludowe. Dokumentacje takich bibliotek czy wystaw stają się na lata, a w niektórych wypadkach na zawsze, substytutem bibliografii ${ }^{3}$.

Wydaje się, że bibliolodzy i blibliotekarze polscy mają zbyt mało zrozumienia dla polityki małych kroków. Wolno twierdzić, że efektywność jest po stronie mniejszych, cząstkowych, szybciej publikowanych opracowań liczących się z tym, że przez pewien czas będą one jedyne. Znacznie więcej zbiorów może zostać spisanych, niż w całości przechowanych, a zwłaszcza pozostawionych w lokalach, które zajmowały wraz z poprzednimi właścicielami. Większość pozycji w dwudziestowiecznych księgozbiorach z natury rzeczy dubluje pozycje, które znajdują się już w dużych bibliotekach kraju. 
Aby na podstawie tych cząstkowych prac można było w przyszłości stworzyć obraz dziejów księgozbiorów polskich, konieczne jest przygotowanie dokumentacji scalającej opisy zarejestrowanych bibliotek, zarówno tych, które się zachowały, jak i tych, o których mamy wiadomości pośrednie, np. w katalogach wystaw. To zadanie na najbliższą przyszłość. Ważne jest też opracowanie zasad opisu ksieggozbioru jako całości. Przy czym nie wydaje się najefektywniejszą drogą wykonywanie dokładnych opisów katalogowych całości według jednolitych zasad. Pewne obiekty lub zespoły wymagają szczególowego opisu, inne mogą być odnotowane z możliwie najmniejszym nakładem sił i środków, tak, aby można było zidentyfikować druk w dostępnych bibliografiach i katalogach. W określonych wypadkach wystarczająca okaże się grupowa rejestracja zbiorów.

Należy żywić nadzieję, że powołana z inicjatywy Polskiego Towarzystwa Bibliologicznego Pracownia Dokumentacji Księgozbiorów Historycznych, działająca w Bibliotece Narodowej, potrafi bez zbędnej akrybii dostarczyć jeszcze za życia naszego pokolenia przydatnych bibliotekarzom, księgoznawcom i bibliofilom informacji.

$\mathrm{Na}$ zakończenie refleksja - dla rozwoju kultury potrzebne jest budowanie kolejnych księgozbiorów oraz wzbogacanie żywych placówek. Losem ksiażek jest nie tylko skupianie, ale i rozpraszanie, wędrówki, które pozwalają na nieustanną, twórczą pracę nad powstawaniem nowych kolekcji.

\section{Przypisy}

${ }^{1}$ O wykorzystaniu archiwów do poznawania księgozbiorów por. m.in. M.J. Lech, Ludzie druku i ksiażzki w Królestwie Polskim 1867-1907, Warszawa 1983; H. Chamerska, Akta hipoteczne i notarialne jako źródio badań nad księgozbiorami prywatnymi XIX-XX W., [W:] Z badań nad księgozbiorami historycznymi. Z. 5, 1981, s. 5-18.

${ }^{2}$ Przykładem dokumentacji ważniejszych zbiorów, które weszły w skład biblioteki jest katalog wystawy Staatsbibliothek w Berlinie - „Was du ererbt..." 1986, w Polsce Muzeum Narodowe we Wroctawiu opracowało sylwetki osób, których zbiory, m.in. ksiażki, znalazły się w tym Muzeum. Por. „Kolekcjonerzy i miłośnicy" 1988.

${ }^{3} \mathrm{~W}$ tekście przywolano tylko nieliczne przykłady. Istnieje w Polsce I na świecie wiele opisów księgozbiorów, ich katalogów, m.in. z okazji wystaw, sprzedaży (aukcji) itp. Opracowanie tego materiału, a nawet jego spisanie, przekracza ramy obecnego artykułu. 